\title{
Combining lexical and context features for automatic ontology extension
}

\author{
Sara Althubaiti ${ }^{1,2}$, Şenay Kafkas ${ }^{1,2}$ (D), Marwa Abdelhakim ${ }^{1,2}$ and Robert Hoehndorf ${ }^{1,2^{*}}$
}

\begin{abstract}
Background: Ontologies are widely used across biology and biomedicine for the annotation of databases. Ontology development is often a manual, time-consuming, and expensive process. Automatic or semi-automatic identification of classes that can be added to an ontology can make ontology development more efficient.

Results: We developed a method that uses machine learning and word embeddings to identify words and phrases that are used to refer to an ontology class in biomedical Europe PMC full-text articles. Once labels and synonyms of a class are known, we use machine learning to identify the super-classes of a class. For this purpose, we identify lexical term variants, use word embeddings to capture context information, and rely on automated reasoning over ontologies to generate features, and we use an artificial neural network as classifier. We demonstrate the utility of our approach in identifying terms that refer to diseases in the Human Disease Ontology and to distinguish between different types of diseases.

Conclusions: Our method is capable of discovering labels that refer to a class in an ontology but are not present in an ontology, and it can identify whether a class should be a subclass of some high-level ontology classes. Our approach can therefore be used for the semi-automatic extension and quality control of ontologies. The algorithm, corpora and evaluation datasets are available at https://github.com/bio-ontology-research-group/ontology-extension.
\end{abstract}

Keywords: Disease ontology, Embeddings, Neural network

\section{Background}

The biomedical community has spent significant resources to develop biomedical ontologies which contain and define the basic classes and relations that occur within a domain. Biomedical ontologies are developed by domain experts and are often developed in conjunction with the needs arising in literature-based curation of biological databases.

Manual curation of databases based on literature is a very time-consuming task due to the massive amounts of literature, and automated methods have been developed early on to aid in curation [1]. One of the key tasks in computational support for literature curation is the automatic concept recognition of mentions of ontology classes in text [2]. An ontology class is an intensionally defined

\footnotetext{
${ }^{*}$ Correspondence: robert.hoehndorf@kaust.edu.sa

${ }^{1}$ Computational Bioscience Research Center, King Abdullah University of

Science and Technology, 23955-6900 Thuwal, Saudi Arabia

${ }^{2}$ Computer, Electrical and Mathematical Sciences and Engineering Division,

King Abdullah University of Science and Technology, 23955-6900 Thuwal,

Saudi Arabia
}

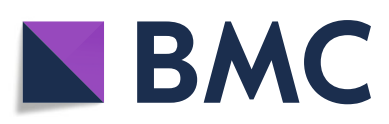

(C) The Author(s). 2020 Open Access This article is distributed under the terms of the Creative Commons Attribution 4.0 International License (http://creativecommons.org/licenses/by/4.0/), which permits unrestricted use, distribution, and reproduction in any medium, provided you give appropriate credit to the original author(s) and the source, provide a link to the Creative Commons license, and indicate if changes were made. The Creative Commons Public Domain Dedication waiver (http://creativecommons.org/publicdomain/zero/1.0/) applies to the data made available in this article, unless otherwise stated. natural language, multiple terms and phrases can be used to refer to an ontology class [4], and the formal dependencies within an ontology further determine whether a term refers to a class or not (i.e., whether a term refers to a particular class may depend on background knowledge, in particular subclass relations, contained in an ontology). For example, the Disease Ontology (DO) [5] declares Prediabetes syndrome (DOID:11716) to be a subclass of Diabetes mellitus (DOID:9351), and based on this information we assume that any reference to, or mention of, Prediabetes syndrome is also a reference to Diabetes mellitus (with respect to DO).

There are several text mining systems designed for ontology concept recognition in text. These methods are either based on lexical methods and therefore applicable to a wide range of ontologies $[6,7]$ or they are domainspecific and rely on machine learning [8]. Text mining entity that has a formal description within an ontology and 
based-methods can also be used to automatically or semiautomatically construct and extend ontologies $[9,10]$. For example, Lee et al. [11] focus on text mining of relations that are asserted in text between mentions of ontology classes that has been used to refine ontology classes in the Gene Ontology (GO) [12]. Text mining can also be used to suggest new subclasses and sibling classes in ontologies, for example Wächter and Schroeder [13] carried out a text mining based-system from different text sources which is used for extending $\mathrm{OBO}$ ontologies by semi-automatically generating terms, definitions and parent-child relations. Xiang et al. [14] have developed a pattern-based system for generating and annotating a large number of ontology terms, following ontology design patterns and providing logical axioms that may be added to an ontology. Recently, clustering based on statistical co-occurrence measures were also used to extend ontologies [15].

Here, we introduce a novel method relying on machine learning to identify whether a word used in text refers to a class that could be included in a particular ontology. Essentially, our method classifies terms to determine if they are usually mentioned in the same context as the labels and synonyms of classes in an ontology (which are used as seeds to train the classifier); this classifier can then be applied to unseen terms. Furthermore, our method can also be used to expand ontologies by suggesting terms that are mentioned within the same context as specific classes in an ontology.

We demonstrate the utility of our method in identifying words referring to diseases from DO in full text articles. We select the DO because the labels and synonyms of DO classes are relatively easy to detect in text and a large number of computational methods rely on access to a comprehensive disease ontology [16-19]. Our method achieves highly accurate (F-score $>90 \%$ ) and robust results, is capable of recognizing multiple different classes including those defined formally through logical operators, and combines dictionary-based and contextbased features; therefore, our method is also capable of finding new words that refer to a class. We manually evaluate the results and suggest several additions to the DO.

\section{Methods}

\section{Building a disease dictionary}

We built a dictionary from the labels and synonyms of classes in the Disease Ontology (DO), downloaded on 5 February 2018 from http://disease-ontology.org/ downloads/. The dictionary consisted of 21,788 terms belonging to 6,831 distinct disease classes from DO. We utilized the dictionary with the Whatizit tool [20] and annotated the ontology class mentions along with their identifiers in approximately 1.6 million open access fulltext articles from the Europe PMC database [21] (http:// europepmc.org/ftp/archive/v.2017.06/) and generated a corpus annotated with mentions of classes in DO. We preprocessed the corpus by removing stop words such as "the", "a", and "is" as well as some punctuation characters.

\section{Generating context-based features}

We use Word2Vec [22] to generate word embedding. Specifically, we use a skip-gram model which aims to find word representations that are useful for predicting the surrounding words in a given sentence or a document consisting of sequence of words; $w_{1}, w_{2}, \ldots, w_{K}$. The objective is to maximize the average log probability using the following formula:

$$
V(w)=\frac{1}{K} \sum_{k=1}^{K} \sum_{-c \leq j \leq c ; j \neq 0}^{K} \log p\left(w_{K+j} \mid w_{K}\right)
$$

where word vectors $V(w)$ are computed by averaging over the number of words $K$ and $c$ is the size of the training context. We generated the word embedding by using the default parameter settings of the Word2Vec gensim implementation: vector size (dimensionality) of 100, window size 5 , minimum occurrence count of 5 , and we use a skip-gram (sg) model.

\section{Supervised training}

We carried out a set of experiments to choose the optimal training algorithm to design our model. In our experiments we used default parameters for the training algorithms but different hidden layers for Artificial Neural Networks (ANNs) [23]. Our experiments show that the ANN model outperforms an SVM model [24] (see Additional file 1: Table 1 for full details), and our model performs best with 200 neurons in a single hidden layer (we tested a single hidden layer with a size of 10,50, 100 , and 200 neurons). We report results accordingly to a model with 200 neurons in the remainder of this work. In ANNs, multiple neurons are organized in layers. Typically, different layers perform different kinds of transformations on their inputs [25]. In our experiments, we used an ANN with an input layer of different sizes, a single hidden layer that uses a sigmoid activation function, and an output layer that differs based on the experiment. We train each classifier in a supervised manner, using 10-fold stratified cross-validation. Additionally, we report testing performance on an independent $20 \%$ testing set which we generated by randomly removing data points before training.

\section{Recognizing ontology classes in text}

We used two approaches to recognize the mention of ontology classes in text. Our first approach relies solely on labels and synonyms of the classes within a given ontology $O$ and can be used to determine whether a word refer 
to a class in $O$. We first obtain an ontology $O$ in the Web Ontology Language (OWL) [26] format and extract a list of class labels and synonyms $L$ from $O$; we further utilize a text corpus $T$ as input to our method. Then, we generate word embeddings (i.e., vector-space encodings of the contexts in which a word occurs) for all words in our text corpus $T$ and train a supervised machine learning model to classify whether a word refers to a class in $O$ or not (using the $L$ 's words as positive training instances and all others as negative instances).

Figure 1 illustrates the workflow of our first approach. Our method is generic and can, in principle, be applied to any ontology as long as the ontology provides labels (or synonyms), these labels can be identified in text, and the ontology from which the labels are extracted is more or less limited to a single domain. For example, reference ontologies in the OBO Foundry [27] are usually single domain ontologies and therefore suitable for our method. Ontologies that would not be suitable are application ontologies that cover multiple domains, such as the Experimental Factor Ontology (EFO) [28] (although our methods can be applied to parts of it). It is most useful to extend an existing ontology with new labels, synonyms, or classes.

In our second approach, we rely on annotations from the Whatizit tool [20] to identify the mention of ontology classes in text and determine their specific superclasses in an ontology. Our approach takes an ontology $O$ in OWL format, a set of ontology classes $S=\left\{C_{1}, \ldots, C_{n}\right\}$, and a corpus of text $T$ as inputs.

This approach first uses Whatizit as a named entity recognition and normalization tool to normalize class labels and synonyms in text by replacing all mentions of a class with the class identifier (i.e., the class URI). We annotate 15,183 distinct terms using Whatizit; the total dictionary consists of 21,788 terms (derived from the labels and synonyms of classes in DO). We then train Word2Vec model that captures the context of the mention of the class and generates a vector space embedding for that class. Given such vector space embeddings for a set of classes in $O$, we use the vector space embeddings as input to a machine learning method that classifies whether another class appears in a similar context. We use this method to determine if a class should belong the superclass of $C$ in $O$. Figure 2 illustrates the workflow of this approach.

The main difference between the two approaches is that the first approach broadly identifies terms or words that refer to classes within a domain (as defined by the sum of classes within an ontology) while the second approach can determine whether a term or word refers to a class that should appear as a subclass of a more specific ontology class. Both methods generate "seed" words in text and then use these seeds first to generate context-based features (through Word2Vec) and use these context-based features in a supervised machine learning classifier.

\section{Manual analysis process}

We manually evaluate some of our findings. The manual evaluation is based on the medical expert knowledge of the evaluator who is a trained clinician, and supplemented by literature search to validate some findings or resolve conflicts. Mainly, results were confirmed by searching for review papers that characterize a condition. Overall,

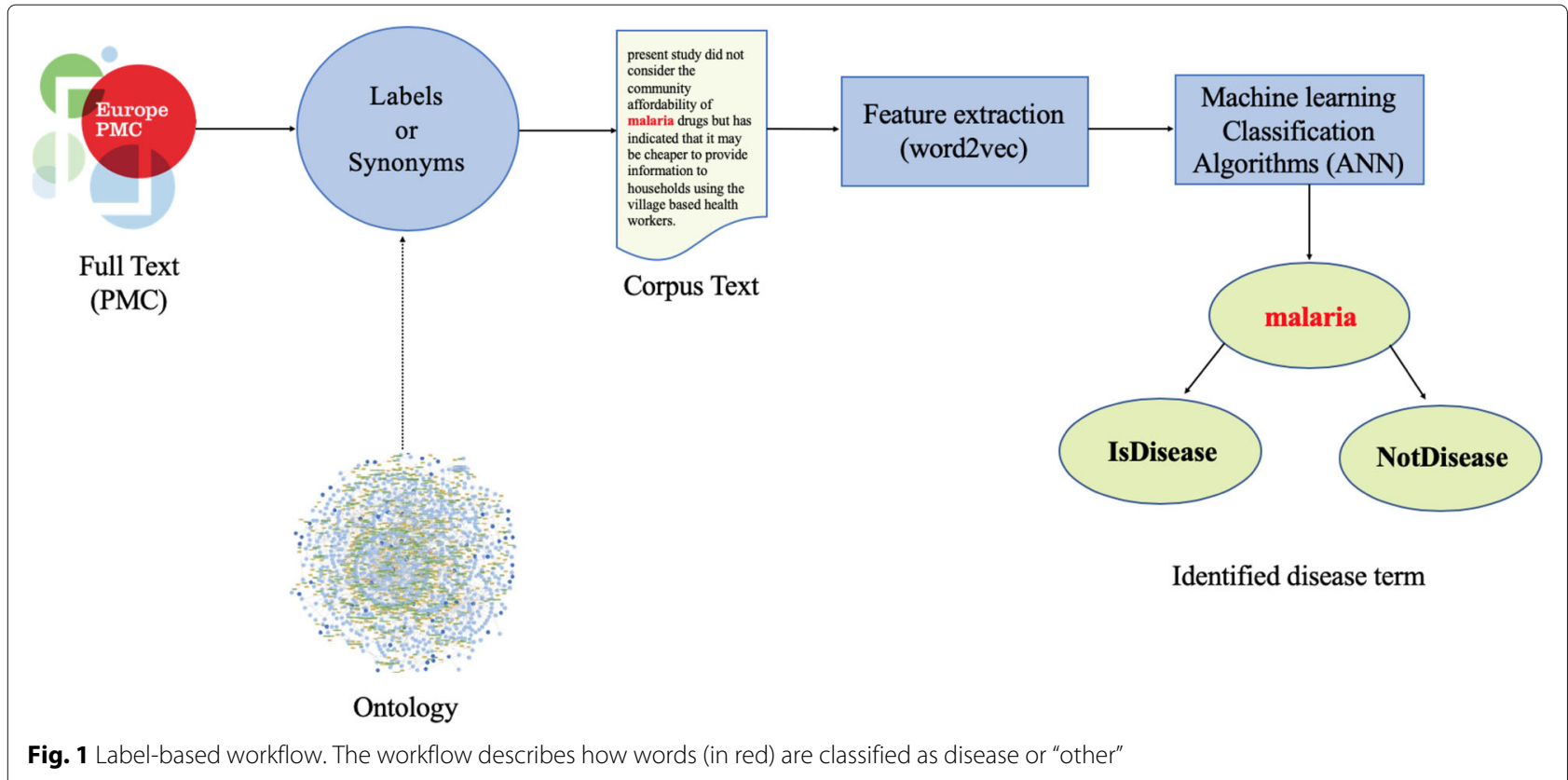

Fig. 1 Label-based workflow. The workflow describes how words (in red) are classified as disease or "other" 


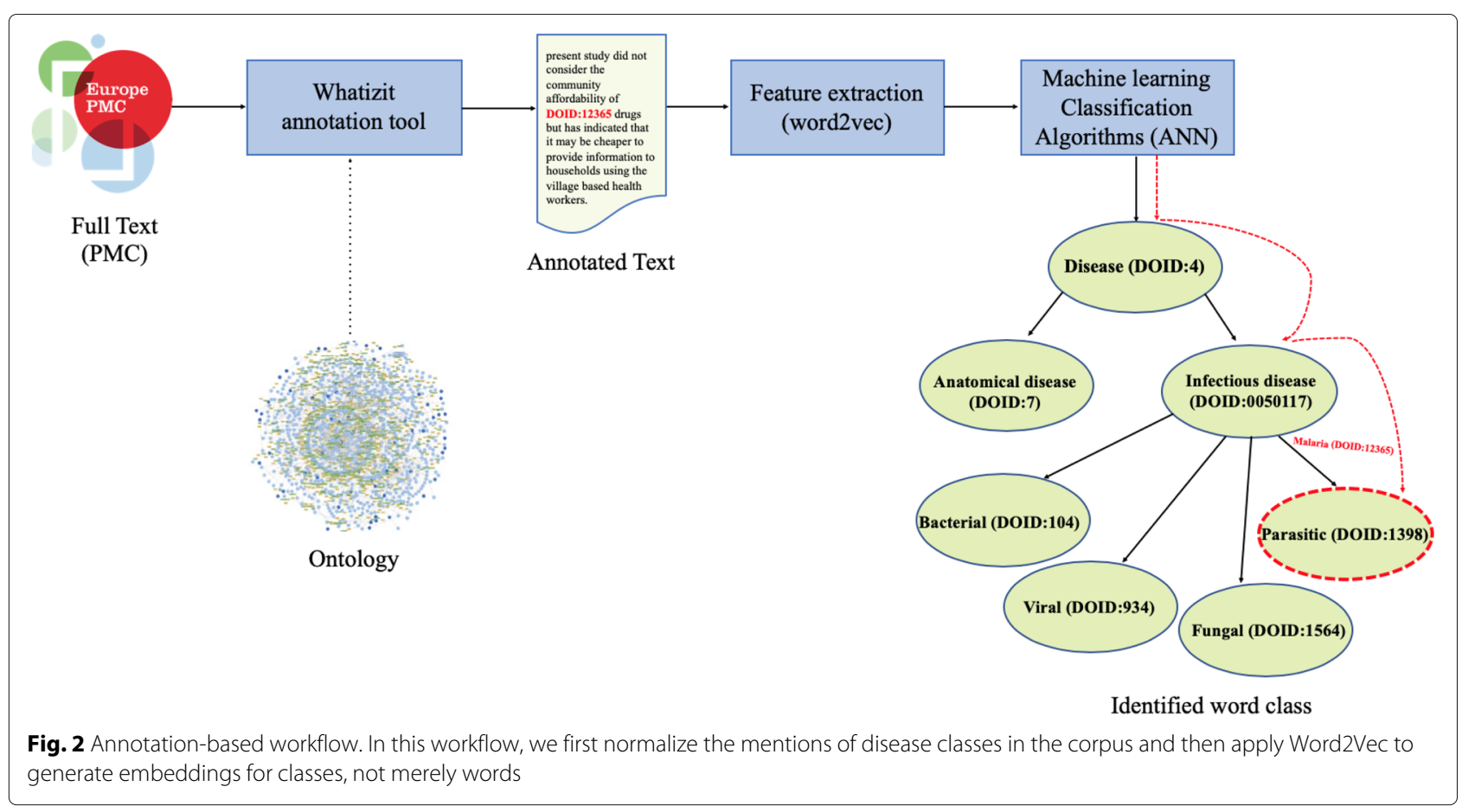

manual curation following the suggestions by our classifier took 10-15 min per sample (which included identifying related classes in the DO and drafting an explanation for cases which disagree with the DO).

\section{Results}

\section{Broad classification of domain-specific terms: application to diseases}

Our method is a workflow that can be used to identify whether a term or phrase commonly refers to a class that may be included in a domain-specific ontology as a label, synonym, or a new class. To achieve this goal, we use the existing labels and synonyms within a domainontology as "seeds" to train a machine learning classifier that determines whether a new term is sufficiently similar to an existing label or synonym and may therefore also be included in the ontology. We represent terms primarily by the context in which they occur within a large corpus of text; we use Word2Vec [22] for this purpose. We then train an Artificial Neural Network classifier in a supervised manner to distinguish between the terms already included within a domain ontology (and therefore expected to refer to a particular kind of phenomena) and randomly chosen terms not included in the ontology (and therefore most likely not referring to a phenomenon within the domain of the ontology).

We demonstrate our method using the Human Disease Ontology (DO) [5] and applying it to the terms occurring in a large corpus of full-text biomedical articles (see "Methods"). First, we tested whether our approach is capable of identifying words that refer to the Disease class (DOID:4), i.e., whether our method can detect terms that refer to a disease. We generated word embeddings for every disease terms and other words in our corpus of full-text articles.

Figure 3 illustrates the distribution of the terms referring to a diseases in DO and other words mentioned in our corpus which do not belong to DO using the t-SNE dimensionality reduction [29]. We can see that the terms are clearly different and should be separable through a machine learning system.

Therefore, we trained a machine learning model to recognize whether a word refers to the disease or not using the word embeddings as input. We split the vector space embeddings into a training and testing dataset and consider all embeddings referring to disease as positive instances and all others as negatives. We do not apply any filtering before selecting the positive or negative samples. We randomly select negatives equal to the number of positives (7,932 positives and 7,932 negatives). We withhold $20 \%$ of randomly chosen positive and negative instances for testing, train a model on the remaining $80 \%$ through 10 -fold cross validation, and report the performance results on the $20 \%$ test set. Evaluated on the testing set, we can distinguish between disease and non-disease terms with an F-score of $95 \%$ and AUC of $96 \%$ (see Table 1 and Figure 4).

To better understand the source of errors and whether our approach can be used to reliably extend ontologies (either with additional labels and synonyms, or new 


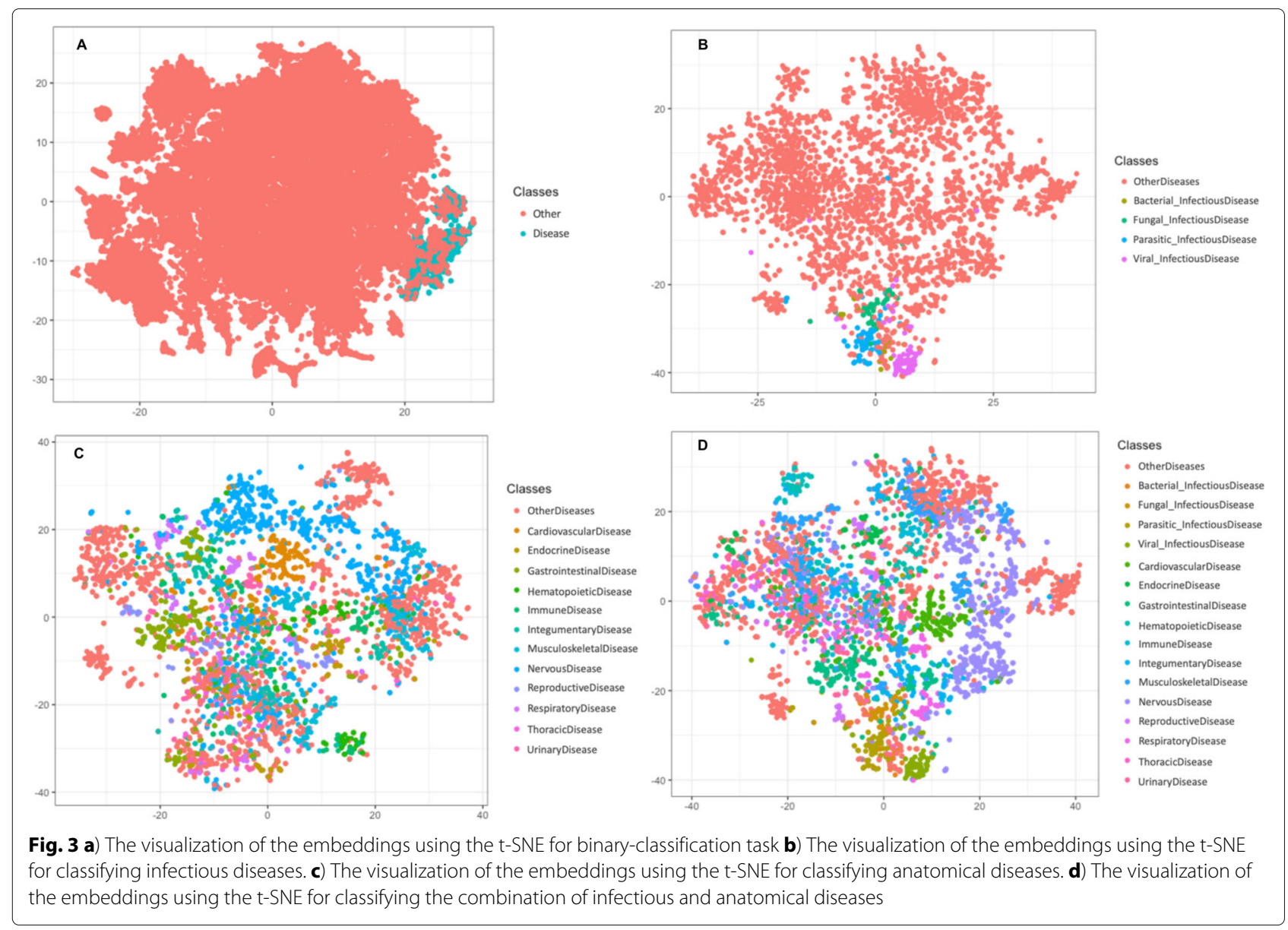

classes), we performed a manual analysis on a set of 20 false positive samples out of 197 which are not the label or synonym of a disease class DO but are classified as disease by our classifier (see Table 2). We found that the majority of the 20 false positive samples refer to either diseases or phenotypes (where phenotypes are the observable characteristics of an organism that may occur manifestations, or signs and symptoms, of a disease, but do not constitute a disease on its own). For example, Aphthosis is a prediction of our method which refers to a human disorder that is not currently in the DO; the majority of false positives are disease-related terms that do not explicitly refer to a disease. For example, we predicted mal-absorption as a disease term which may refer to a phenotype in some contexts. Our findings indicate that an ANN classifier can identify known terms referring to diseases, and can further suggest novel terms which may prove useful for ontology development and extension.

\section{Fine-grained classification: distinguishing between groups of diseases}

As our method showed capability to identify terms referring to a disease, we next tested whether our method can also distinguish between different types of diseases. For this purpose, we used the embeddings generated from a pre-processed corpus in which we normalize all mentions

Table 1 F-score and AUC for our four experiments using different hidden layer sizes

\begin{tabular}{|c|c|c|c|c|c|c|c|c|c|}
\hline \multirow[t]{2}{*}{ Classification } & \multirow{2}{*}{$\begin{array}{l}\text { Hidden layer sizes } \\
\text { Number of classes }\end{array}$} & \multicolumn{2}{|l|}{10} & \multicolumn{2}{|l|}{50} & \multicolumn{2}{|l|}{100} & \multicolumn{2}{|l|}{200} \\
\hline & & F-score & AUC & F-score & $A \cup C$ & F-score & $A \cup C$ & F-score & $A \cup C$ \\
\hline Diseases & 2 & $94.65 \%$ & $95.31 \%$ & $94.83 \%$ & $95.97 \%$ & $95.32 \%$ & $96.06 \%$ & $94.49 \%$ & $95.99 \%$ \\
\hline Infectious disease & 5 & $95.65 \%$ & $95.01 \%$ & $96.01 \%$ & $95.74 \%$ & $95.43 \%$ & $95.22 \%$ & $95.68 \%$ & $96.42 \%$ \\
\hline Anatomical disease & 13 & $69.18 \%$ & $77.22 \%$ & $70.15 \%$ & $80.24 \%$ & $70.20 \%$ & $76.98 \%$ & $72.00 \%$ & $85.11 \%$ \\
\hline Infectious + anatomical diseases & 17 & $71.07 \%$ & $84.75 \%$ & $73.13 \%$ & $84.03 \%$ & $72.61 \%$ & $84.98 \%$ & $72.67 \%$ & $83.66 \%$ \\
\hline
\end{tabular}

The values in bold represent the highest AUC and F-score within each experiments 


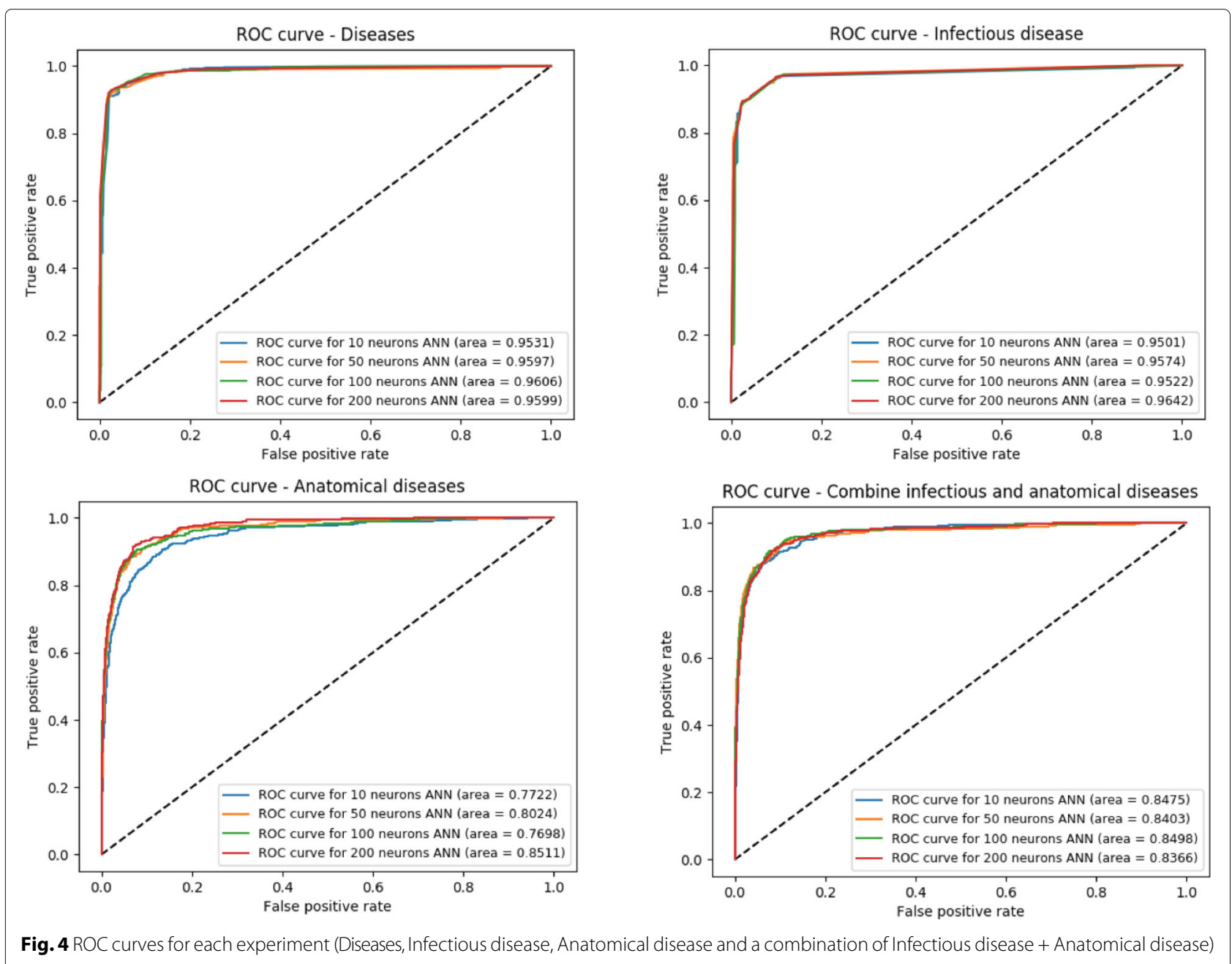

of a disease in our corpus using Whatizit tool. The disease dictionary that we utilized with Whatizit includes a total of 21,788 terms (labels and synonyms) from DO. We found that 15,183 of these 21,788 terms appeared in our corpus and we generate an embedding vector for each of them. We then first trained a neural network model to recognize whether a disease-term refers to the Infectious Disease (DOID: 0 050117) class or not, and furthermore whether our method is able to distinguish between the four different types of infectious disease in DO (i.e., bacterial, fungal, parasitic, or viral infectious disease). As training data, we used the word embeddings generated for DO classes, and we used the Elk reasoner to split them into four types of infectious diseases, and an additional class for diseases that are not a subclass of Infectious Disease in DO. We randomly select $20 \%$ of the disease in $\mathrm{DO}$ as validation set and train the neural network classifier using 10-fold cross-validation on the remaining $80 \%$ to separate diseases into one of the five classes (noninfectious, bacterial, fungal, parasitic and viral infections).
Table 1 shows the performance achieved on the validation set. While the performance is less than predicting whether a term refers to a disease, our classifier can distinguish between specific disease classes.

We manually analyzed a set of 20 false positive samples out of 38 which are not a subclass of Infectious disease in the DO but are classified as infectious by our classifier (see Table 3). We found that 7 of these 20 cases can be suggested to be subclasses of the specific infectious disease they have been classified with but do not have a subclass relation asserted or inferred in DO. For example, the term syphilitic meningitis (DOID:10073) is a disease that our method classify as a bacterial infectious disease but it is not classified as infectious in the DO.

Moreover, to test the strength of our method to distinguish between disease classes, we further trained a neural network model to distinguish between the 12 different subclasses of Disease of anatomical entity (DOID : 7), as well as an additional class for diseases not classified as subclasses of Disease of anatomical entity. We used the 
Table 2 Manually analyzed disease terms predicted as disease

\begin{tabular}{|c|c|c|}
\hline Term & Manual analysis result & Explanation for the suggested diseases \\
\hline FACTO & other & - \\
\hline leucoencephalopathy & other & - \\
\hline Aphthosis & Disease & $\begin{array}{l}\text { A disease refers to a condition with repetitive mucosal ulcers } \\
{[30,31] \text {. }}\end{array}$ \\
\hline Desmoid & other & - \\
\hline metapneumovirus & other & - \\
\hline Tracheobronchomalacia & Disease & $\begin{array}{l}\text { A rare condition with abnormal flaccidity of both the trachea } \\
\text { and the bronchi which results in possibility of narrowing or } \\
\text { collapse of the airway [32-34]. }\end{array}$ \\
\hline RESLES & Disease & $\begin{array}{l}\text { A rare condition characterized by transient lesions in the cen- } \\
\text { tral part of the splenium of the corpus callosum (SCC), followed } \\
\text { by complete reversibility on follow-up magnetic resonance } \\
\text { imaging (MRI) after a variable period. It coincides with different } \\
\text { diseases }[35,36] \text {. }\end{array}$ \\
\hline mal-absorption & other & - \\
\hline acroparesthesias & other & - \\
\hline limb-shaking & other & - \\
\hline pineocytomas & Disease & $\begin{array}{l}\text { A rare disease that has an Orphanet ID: ORPHA : } 251912 \text {. It is } \\
\text { one of the pineal parenchymal tumors and is considered the } \\
\text { least aggressive one }[37,38] \text {. }\end{array}$ \\
\hline hypomineralisation & other & - \\
\hline neurognathostomiasis & Disease & $\begin{array}{l}\text { It is a severe form of human gnathostomiasis, DOID: } 11379 \text {, } \\
\text { which can lead to disease and death, it involves the nervous } \\
\text { system [39-41]. }\end{array}$ \\
\hline Metastasis & other & - \\
\hline myelomatosis & Disease & $\begin{array}{l}\text { A type of cancer that begins in plasma cells that produce anti- } \\
\text { bodies. It could be one of the synonyms of multiple myeloma } \\
\text { DOID : } 9538[42,43] \text {. }\end{array}$ \\
\hline AMRF & Disease & An OMIM disease, OMIM : 254900 [44]. \\
\hline arthralgia & other & - \\
\hline fibrodentinoma & Disease & $\begin{array}{l}\text { Fibrodentinoma is a benign odontogenic tumor that occurs } \\
\text { in children and young adults. The disease name usually is } \\
\text { represented as "Ameloblastic Fibrodentinoma" }[45,46] \text {. }\end{array}$ \\
\hline infantile-ataxia & other & - \\
\hline knowlesi & other & - \\
\hline
\end{tabular}

The terms in bold represent the correctly validated terms (by a clinician) that classified as diseases terms using our method (in Diseases classification experiment).

same method to split the classes in training and test set as before. Results are shown in Table 1 and demonstrate that our method can also be useful to classify diseases in their anatomical sub-systems.

We manually analyzed a set of 20 false positive samples out of 127 which are not a subclass of Anatomical disease in the DO but are classified as being a subclass of a particular anatomical system disease by our classifier (see Table 4). We found that 12 of the 20 false positives can be suggested to be subclasses of the specific anatomical system disease they have been classified with but do not have such a subclass relation asserted or inferred in DO. For example, we classify Narcolepsy (DOID : 8986) as a Nervous system anatomical disease, and this may be added as a new subclass axiom to DO.
As it is often inconvenient to train separate classifiers, we also combined both tasks and trained a multi-class classifier to classify disease classes either as infectious or anatomical, or as other disease. We evaluate the performance of this combined model (see Table 1), and our machine learning system achieves an AUC up to 84\% (see Figure 4). These results demonstrate it may be possible to identify new subclasses, although the performance drops when we increase the complexity of the classification problem by distinguishing between more subclasses.

\section{Discussion}

We developed a method to automatically expand ontologies in the biomedical domain with new classes, synonyms, or axioms. We demonstrate the utility of our 
Table 3 Sample of manually analyzed disease terms predicted as infectious disease

\begin{tabular}{|c|c|c|c|c|c|}
\hline Disease terms & $\begin{array}{l}\text { Ontology class assigned } \\
\text { by ANN }\end{array}$ & Manual analysis result & $\begin{array}{l}\text { Suggested additional } \\
\text { classification }\end{array}$ & DOID & Explanation \\
\hline $\begin{array}{l}\text { Pelizaeus-Merzbacher } \\
\text { disease }\end{array}$ & Viral infectious disease & $\begin{array}{l}\text { Non-infectious (inherited } \\
\text { disorder) }\end{array}$ & - & - & - \\
\hline Kaposi's sarcoma & Viral infectious disease & Viral infectious disease & herpes simplex & DOID:8566 & $\begin{array}{l}\text { The disease is caused by } \\
\text { Human herpesvirus } 8 \\
\text { which is Herpesviridae } \\
\text { infection. }\end{array}$ \\
\hline maxillary sinusitis & Bacterial infectious disease & $\begin{array}{l}\text { Bacterial infectious disease } \\
\text { (usually start viral and } \\
\text { progress to either } \\
\text { bacterial or fungal) }\end{array}$ & - & - & $\begin{array}{l}\text { It is an infection in the } \\
\text { maxillary sinuses which } \\
\text { could be due to different } \\
\text { etiology, one of them is } \\
\text { bacterial [47]. }\end{array}$ \\
\hline keratosis follicularis & Bacterial infectious disease & $\begin{array}{l}\text { Non-infectious (genetic } \\
\text { disease) }\end{array}$ & - & - & - \\
\hline $\begin{array}{l}\text { chronic rheumatic } \\
\text { pericarditis }\end{array}$ & Viral infectious disease & $\begin{array}{l}\text { The condition is triggered } \\
\text { by autoimmune reaction } \\
\text { to infection, mainly group } \\
\text { A streptococci. }\end{array}$ & - & - & - \\
\hline gastroparesis & Viral infectious disease & $\begin{array}{l}\text { In most cases the nerve is } \\
\text { damaged by diabetes or } \\
\text { surgery, however, a viral } \\
\text { infection might be a cause }\end{array}$ & - & - & $\begin{array}{l}\text { A condition in which the } \\
\text { stomach suffers from } \\
\text { paresis that affects the } \\
\text { food movement to the } \\
\text { small intestine }[48,49] \text {. }\end{array}$ \\
\hline osmotic diarrhea & Bacterial infectious disease & symptom & - & - & - \\
\hline $\begin{array}{l}\text { familial cold } \\
\text { autoinflammatory } \\
\text { syndrome }\end{array}$ & Viral infectious disease & $\begin{array}{l}\text { Non-infectious (inherited } \\
\text { disease) }\end{array}$ & - & - & - \\
\hline angular cheilitis & Fungal infectious disease & $\begin{array}{l}\text { Etiology is controversial, } \\
\text { most commonly fungal or } \\
\text { bacterial. }\end{array}$ & - & - & Ambiguous. \\
\hline Binder syndrome & Viral infectious disease & Congenital disease & - & - & - \\
\hline hypohidrosis & Bacterial infectious disease & Multi-causal & - & - & - \\
\hline Sjogren's syndrome & Viral infectious disease & autoimmune disease & - & - & - \\
\hline $\begin{array}{l}\text { median rhomboid } \\
\text { glossitis }\end{array}$ & Fungal infectious disease & $\begin{array}{l}\text { Etiology is controversial, } \\
\text { however it is considered } \\
\text { as a variant of orallesion } \\
\text { associated with candida } \\
\text { infection [50]. }\end{array}$ & - & - & Ambiguous. \\
\hline Goodpasture syndrome & Viral infectious disease & autoimmune disease & - & - & - \\
\hline syphilitic meningitis & Bacterial infectious disease & Bacterial infectious disease & syphilis & DOID:4166 & $\begin{array}{l}\text { Considering the same } \\
\text { concept of etiology, both } \\
\text { diseases are caused by } \\
\text { bacterial infection } \\
\text { (Treponema pallidum). }\end{array}$ \\
\hline acute diarrhea & Viral infectious disease & symptom & - & - & - \\
\hline WHIM syndrome & Bacterial infectious disease & Congenital disease & - & - & - \\
\hline erythrasma & Fungal infectious disease & Bacterial infection disease & - & - & - \\
\hline chronic wasting disease & Parasitic infectious disease & $\begin{array}{l}\text { Neurodegenerative } \\
\text { disorder }\end{array}$ & - & - & - \\
\hline scarlet fever & Bacterial infectious disease & Bacterial infectious disease & rheumatic fever & DOID:1586 & $\begin{array}{l}\text { The disease is caused by } \\
\text { Group A bacteria of the } \\
\text { genus Streptococcus, } \\
\text { same causative agent for } \\
\text { Rheumatic fever. }\end{array}$ \\
\hline
\end{tabular}

The terms in bold represent the correctly validated terms (by a clinician) that classified as infectious diseases terms using our method (in Infectious disease classification experiment). 
Table 4 Sample of manually analyzed disease terms classified as affecting particular anatomical systems

\begin{tabular}{|c|c|c|c|c|c|c|}
\hline Disease terms & $\begin{array}{l}\text { Ontology } \\
\text { class }\end{array}$ & $\begin{array}{l}\text { Ontology } \\
\text { class } \\
\text { assigned by } \\
\text { ANN }\end{array}$ & $\begin{array}{l}\text { Manual analysis } \\
\text { result }\end{array}$ & $\begin{array}{l}\text { Suggested } \\
\text { additional } \\
\text { classification }\end{array}$ & DOID & Explanation \\
\hline $\begin{array}{l}\text { Timothy } \\
\text { syndrome }\end{array}$ & $\begin{array}{l}\text { genetic } \\
\text { disease }\end{array}$ & $\begin{array}{l}\text { cardiovascular } \\
\text { system } \\
\text { disease }\end{array}$ & $\begin{array}{l}\text { Cannot specify } \\
\text { (affect multiple } \\
\text { parts) }\end{array}$ & - & - & - \\
\hline $\begin{array}{l}\text { Familial periodic } \\
\text { paralysis }\end{array}$ & $\begin{array}{l}\text { disease of } \\
\text { metabolism }\end{array}$ & $\begin{array}{l}\text { cardiovascular } \\
\text { system } \\
\text { disease }\end{array}$ & $\begin{array}{l}\text { musculoskeletal } \\
\text { system disease }\end{array}$ & - & - & - \\
\hline Hyperprolactinemia & $\begin{array}{l}\text { a disease of } \\
\text { metabolism }\end{array}$ & $\begin{array}{l}\text { endocrine } \\
\text { system } \\
\text { disease }\end{array}$ & $\begin{array}{l}\text { endocrine system } \\
\text { disease }\end{array}$ & $\begin{array}{l}\text { pituitary gland } \\
\text { disease }\end{array}$ & DOID:53 & $\begin{array}{l}\text { The pituitary gland is } \\
\text { the endocrine gland } \\
\text { responsible for } \\
\text { secreting prolactin. }\end{array}$ \\
\hline $\begin{array}{l}\text { Angiokeratoma } \\
\text { circumscriptum }\end{array}$ & $\begin{array}{l}\text { disease of } \\
\text { cellular } \\
\text { proliferation }\end{array}$ & $\begin{array}{l}\text { gastrointestinal } \\
\text { system } \\
\text { disease }\end{array}$ & $\begin{array}{l}\text { cardiovascular } \\
\text { system disease }\end{array}$ & - & - & - \\
\hline $\begin{array}{l}\text { Zollinger- } \\
\text { Ellison } \\
\text { syndrome }\end{array}$ & syndrome & $\begin{array}{l}\text { gastrointestinal } \\
\text { system } \\
\text { disease }\end{array}$ & $\begin{array}{l}\text { gastrointestinal } \\
\text { system disease }\end{array}$ & peptic ulcer disease & DOID:750 & $\begin{array}{l}\text { It is a disease that } \\
\text { affects either } \\
\text { pancreas, duodenum, } \\
\text { or both of them. Both } \\
\text { organs are pats of the } \\
\text { GIT system. The } \\
\text { disease pathology } \\
\text { is mainly excessive } \\
\text { gastrin secretion with } \\
\text { subsequent peptic } \\
\text { ulcers. }\end{array}$ \\
\hline $\begin{array}{l}\text { Polycystic liver } \\
\text { disease }\end{array}$ & $\begin{array}{l}\text { genetic } \\
\text { disease }\end{array}$ & $\begin{array}{l}\text { gastrointestinal } \\
\text { system } \\
\text { disease }\end{array}$ & $\begin{array}{l}\text { gastrointestinal } \\
\text { system disease }\end{array}$ & liver disease & DOID:409 & $\begin{array}{l}\text { It is a genetic disorder } \\
\text { that affects primarily } \\
\text { the liver. }\end{array}$ \\
\hline $\begin{array}{l}\text { Bilirubin } \\
\text { metabolic } \\
\text { disorder }\end{array}$ & $\begin{array}{l}\text { disease of } \\
\text { metabolism }\end{array}$ & $\begin{array}{l}\text { hematopoietic } \\
\text { system } \\
\text { disease }\end{array}$ & $\begin{array}{l}\text { hematopoietic } \\
\text { system disease }\end{array}$ & $\begin{array}{l}\text { kernicterus due to } \\
\text { isoimmunization }\end{array}$ & DOID:12043 & $\begin{array}{l}\text { Bilirubin disorder } \\
\text { could be a result of } \\
\text { blood pathology, } \\
\text { same as for the } \\
\text { mentioned } \\
\text { classification } \\
\text { DOID: } 12043 \text {. }\end{array}$ \\
\hline $\begin{array}{l}\text { Alpha } \\
\text { thalassemia }\end{array}$ & $\begin{array}{l}\text { genetic } \\
\text { disease }\end{array}$ & $\begin{array}{l}\text { hematopoietic } \\
\text { system } \\
\text { disease }\end{array}$ & $\begin{array}{l}\text { hematopoietic } \\
\text { system disease }\end{array}$ & hemoglobinopathy & DOID:2860 & $\begin{array}{l}\text { The disease is mainly a } \\
\text { hemoglobin } \\
\text { disorder with } \\
\text { hematological } \\
\text { phenotypes. }\end{array}$ \\
\hline Kabuki syndrome & syndrome & $\begin{array}{l}\text { immune sys- } \\
\text { tem disease }\end{array}$ & $\begin{array}{l}\text { Not anatomical } \\
\text { - multisystems }\end{array}$ & - & - & - \\
\hline Amyloidosis & $\begin{array}{l}\text { disease of } \\
\text { metabolism }\end{array}$ & $\begin{array}{l}\text { immune sys- } \\
\text { tem disease }\end{array}$ & $\begin{array}{l}\text { Not anatomical } \\
\text { multisystems }\end{array}$ & - & - & - \\
\hline Fatty liver disease & $\begin{array}{l}\text { disease of } \\
\text { metabolism }\end{array}$ & $\begin{array}{l}\text { musculoskeletal } \\
\text { system } \\
\text { disease }\end{array}$ & $\begin{array}{l}\text { gastrointestinal } \\
\text { system disease }\end{array}$ & - & - & - \\
\hline $\begin{array}{l}\text { Renal-hepatic- } \\
\text { pancreatic } \\
\text { dysplasia }\end{array}$ & $\begin{array}{l}\text { physical } \\
\text { disorder }\end{array}$ & $\begin{array}{l}\text { musculoskeletal } \\
\text { system } \\
\text { disease }\end{array}$ & $\begin{array}{l}\text { Cannot specify } \\
\text { (affect multiple } \\
\text { parts) }\end{array}$ & - & - & - \\
\hline $\begin{array}{l}\text { Radioulnar syn- } \\
\text { ostosis }\end{array}$ & $\begin{array}{l}\text { physical } \\
\text { disorder }\end{array}$ & $\begin{array}{l}\text { musculoskeletal } \\
\text { system } \\
\text { disease }\end{array}$ & $\begin{array}{l}\text { musculoskeletal } \\
\text { system disease }\end{array}$ & $\begin{array}{l}\text { bone development } \\
\text { disease/Synostosis }\end{array}$ & $\begin{array}{l}\text { DOID:0080006/ } \\
\text { DOID:11971 }\end{array}$ & $\begin{array}{l}\text { There is already an } \\
\text { entity in the DO for } \\
\text { synostosis under } \\
\text { bone development } \\
\text { disease. }\end{array}$ \\
\hline Hypophosphatasia & $\begin{array}{l}\text { genetic } \\
\text { disease }\end{array}$ & $\begin{array}{l}\text { musculoskeletal } \\
\text { system } \\
\text { disease }\end{array}$ & $\begin{array}{l}\text { musculoskeletal } \\
\text { system disease }\end{array}$ & $\begin{array}{l}\text { bone remodeling } \\
\text { disease }\end{array}$ & DOID:0080005 & $\begin{array}{l}\text { We could suggest } \\
\text { an additional } \\
\text { classification based } \\
\text { on the main affected } \\
\text { system. Our } \\
\text { suggestive } \\
\text { classification is } \\
\text { musculoskeletal since }\end{array}$ \\
\hline
\end{tabular}


Table 4 Sample of manually analyzed disease terms classified as affecting particular anatomical systems (Continued)

\begin{tabular}{|c|c|c|c|c|c|c|}
\hline & & & & & & $\begin{array}{l}\text { the disease is mainly } \\
\text { affecting } \\
\text { mineralization of } \\
\text { the bone with } \\
\text { phenotypes similar to } \\
\text { those of Rickets } \\
\text { DOID:10609. }\end{array}$ \\
\hline Narcolepsy & $\begin{array}{l}\text { disease of mental } \\
\text { health }\end{array}$ & $\begin{array}{l}\text { nervous } \\
\text { system } \\
\text { disease }\end{array}$ & $\begin{array}{l}\text { nervous system } \\
\text { disease }\end{array}$ & * & $*$ & $*$ \\
\hline Aceruloplasminemia & disease of metabolism & $\begin{array}{l}\text { nervous } \\
\text { system } \\
\text { disease }\end{array}$ & $\begin{array}{l}\text { nervous system } \\
\text { disease }\end{array}$ & $\begin{array}{l}\text { neurodegeneration } \\
\text { with brain iron } \\
\text { accumulation }\end{array}$ & DOID:0110734 & $\begin{array}{l}\text { The disease main } \\
\text { pathophysiology is } \\
\text { either the absence } \\
\text { or dysfunction of } \\
\text { ceruloplasmin with } \\
\text { subsequent iron } \\
\text { accumulation in } \\
\text { various organ, mainly } \\
\text { the brain. }\end{array}$ \\
\hline Glomangiomatosis & $\begin{array}{l}\text { disease of cellular pro- } \\
\text { liferation }\end{array}$ & $\begin{array}{l}\text { nervous } \\
\text { system } \\
\text { disease }\end{array}$ & $\begin{array}{l}\text { cardiovascular } \\
\text { system disease }\end{array}$ & - & - & - \\
\hline $\begin{array}{l}\text { Deafness-dystonia- } \\
\text { optic neuronopathy } \\
\text { syndrome }\end{array}$ & disease of metabolism & $\begin{array}{l}\text { nervous sys- } \\
\text { tem disease }\end{array}$ & $\begin{array}{l}\text { nervous system } \\
\text { disease }\end{array}$ & $\begin{array}{l}\text { nervous system } \\
\text { disease; since it } \\
\text { covers many } \\
\text { subclasses to } \\
\text { which we can map } \\
\text { many aspects of } \\
\text { this disease }\end{array}$ & DOID:863 & $\begin{array}{l}\text { The disease's } \\
\text { phenotypes reflect } \\
\text { neurological affection } \\
\text { of multiple parts in the } \\
\text { nervous system. }\end{array}$ \\
\hline $\begin{array}{l}\text { Trophoblastic } \\
\text { neoplasm }\end{array}$ & $\begin{array}{l}\text { disease of cellular } \\
\text { proliferation }\end{array}$ & $\begin{array}{l}\text { reproductive } \\
\text { system } \\
\text { disease }\end{array}$ & $\begin{array}{l}\text { reproductive } \\
\text { system disease }\end{array}$ & $\begin{array}{l}\text { Female } \\
\text { reproductive organ } \\
\text { cancer }\end{array}$ & DOID:120 & $\begin{array}{l}\text { The term refers to the } \\
\text { group of } \\
\text { malignant neoplasms } \\
\text { that consist of } \\
\text { abnormal } \\
\text { proliferation of } \\
\text { trophoblastic tissues } \\
\text { similar to } \\
\text { choriocarcinoma } \\
\text { DOID: } 3596 \text { and } \\
\text { gestational } \\
\text { trophoblastic } \\
\text { neoplasia } \\
\text { DOID: } 3590 \text {. }\end{array}$ \\
\hline Cryptorchidism & physical disorder & $\begin{array}{l}\text { reproductive } \\
\text { system } \\
\text { disease }\end{array}$ & $\begin{array}{l}\text { reproductive } \\
\text { system disease }\end{array}$ & testicular disease & DOID:2519 & $\begin{array}{l}\text { The term refers to } \\
\text { undescended testicle. }\end{array}$ \\
\hline
\end{tabular}

*Nacrolepsy: is classified as a sleep disorder which is correct, however, the class itself is a subclass to mental disorders. Since there are some neurological disorders that have shown a strong association with sleep disorder such as: neurodenegrative disorders such as tauopathy which involve Alzheimer's diseases (DOID : 10652) [51], synucleinopathy which involve Parkinsonism (DOID : 14330) [52], and Genetic neurodegenerative disorders such as Machado-Joseph disease (DOID : 144 0) [53] or Huntington's disease (DOID : 12 858) [54]. We suggest a new classification in which sleep disorders may also be a subclass of nervous system diseases (neurodegenerative disorder) [55] The terms in bold represent the correctly validated terms (by a clinician) that classified as anatomical diseases terms using our method (in Anatomical disease classification experiment).

approach on the DO [5] which is widely used in biomedical research [56]. As case studies, we focused on two high-level classes in the DO: Infectious Diseases and Anatomical Diseases. We have evaluated our method both using common performance measures in machine learning as well as through manually investigating some of the predicted false positives.

When applying our method to the DO, our false positive predictions often include phenotypes or, in some cases, pathogens. It is well-established that it is challenging to distinguish between diseases and phenotypes in literature [57-59], as evidenced by the large overlap between disease ontologies and phenotype ontologies [19]. Similarly, diseases and pathogens can often have very similar names [60,61], thereby making it challenging to distinguish between them. While a disease is defined as the structural or functional disorder that usually results in symptoms, signs and physical or chemical changes, phenotype refers to observable characteristics of an organism and may be a part of a disease manifestation. Phenotype 
terms cover disease symptoms, signs and the investigational results that might be related to that disease. Some phenotypic terms are more diverse; for example, congenital hemolytic anemia is a form of hemolytic anemia with congenital onset. The term is included in both the Human Phenotype Ontology (HP) (HP:0004804) and disease ontology (DOID: 589). From a clinical point of view, it could be a type of disease under the umbrella of hemolytic disorders with a congenital onset; however, congenital hemolytic anemia may also be a phenotype for certain diseases. For this reason, deciding on some terms to be identified either as phenotypes or diseases can be complex, challenging, and context-dependent.

Another limitation of our method is the use of the Whatizit tool [20] to detect and normalize mentions of ontology classes in text. In our first use-case - the extension of ontologies with new labels and synonyms - we classify terms that occur in text without relying on any prior text processing which has some drawbacks such as considering a word as disease name within a general context. We use Whatizit for our second use-case - the detection of subclass axioms - while the performance of Whatizit is less than domain- and task-specific named entity recognition and normalization tools [62], Whatizit's key advantage is that it is a lexical, rule-based method that does not require any training and is able to recognize multi-word terms. Whatizit can therefore be applied to a wide range of ontologies without the need to generate a training dataset. To evaluate the performance of Whatizit, we tested it on the NCBI disease corpus [16] using their test set containing 100 abstracts. In our evaluation, Whatizit has a precision of $75 \%$ and recall of $15 \%$ and an F-score of $26 \%$ with an accuracy of $90 \%$ (see Additional file 2). One of the reasons for the low recall is the number of diseases which are included in the Medical Subject Headings (MeSH) [63] or the Online Mendelian Inheritance in Man (OMIM) [64] vocabulary but not in DO. Furthermore, Whatizit ignores many disease abbreviations since they are not included in DO (and therefore in the vocabulary used by Whatizit).

\section{Conclusions}

We presented a general method for semi-automatically extending ontologies with new labels, synonyms, classes, or some general subclass axioms. Our approach is based on machine learning algorithms utilizing vector representation of the ontology classes generated from full text articles. We demonstrated the utility of our approach on the Human Disease Ontology (DO), specifically by finding new candidate classes, labels, and synonyms to add to DO such as Aphthosis, and by identifying new axioms that relate disease classes to their infectious agent or anatomical systems. Our method can help to improve the quality and coverage of ontologies in the ontology development process by automatically suggesting terms to include (either as labels of new classes or synonyms of existing classes) and suggesting missing subclass axioms. In the future, we plan to expand our study to other ontologies and to defined classes to further analyze its robustness.

\section{Supplementary information \\ Supplementary information accompanies this paper at https://doi.org/10.1186/s13326-019-0218-0.}

Additional file 1: Different conducted experiments based on different classification tasks.

Additional file 2: The evaluation of analyzing NCBI abstracts annotated using Whatizit tool.

\section{Abbreviations}

ANNs: Artificial neural networks; AUC: Area under curve; DO: Disease ontology; EFO: Experimental factor ontology; GO: Gene ontology; HP: human phenotype ontology; MeSH: Medical subject headings; OMIM: Online mendelian inheritance in man; OWL: Web ontology language; ROC: Receiver operating characteristic; Sg: Skip-gram

\section{Acknowledgement}

Not applicable.

\section{Authors' contributions}

$\mathrm{RH}$ conceived of the study; SKK, SA, and RH designed the experiments. SA conducted the experiments, implemented the software and evaluated the results. MA manually evaluated the results. SA drafted the manuscript; ŞK and $\mathrm{RH}$ contributed to revising the manuscript. All authors have read and approved the final version of the manuscript.

\section{Funding}

This work was supported by funding from King Abdullah University of Science and Technology (KAUST) Office of Sponsored Research (OSR) under Award NoÜRF/1/3454-01-01, FCC/1/1976-08-01, and FCS/1/3657-02-01.

\section{Availability of data and materials}

All source code developed for this study is available from https://github.com/ bio-ontology-research-group/ontology-extension.

Ethics approval and consent to participate

Not applicable.

\section{Consent for publication}

Not applicable.

\section{Competing interests}

The authors declare that they have no competing interests.

Received: 2 October 2018 Accepted: 24 December 2019

Published online: 13 January 2020

\section{References}

1. Müller H-M, Kenny EE, Sternberg PW. Textpresso: an ontology-based information retrieval and extraction system for biological literature. PLoS Biol. 2004;2(11):309.

2. Rebholz-Schuhmann D, Oellrich A, Hoehndorf R. Text-mining solutions for biomedical research: enabling integrative biology. Nat Rev Genet. 2012;13(12):829.

3. Hoehndorf R, Schofield PN, Gkoutos GV. The role of ontologies in biological and biomedical research: a functional perspective. Brief Bioinform. 2015;16(6):1069-80.

4. Tseytlin E, Mitchell K, Legowski E, Corrigan J, Chavan G, Jacobson RS. Noble-flexible concept recognition for large-scale biomedical natural language processing. BMC Bioinformatics. 2016;17(1):32. 
5. Schriml LM, Arze C, Nadendla S, Chang Y-WW, Mazaitis M, Felix V, Feng G, Kibbe WA. Disease ontology: a backbone for disease semantic integration. Nucleic Acids Res. 2011;40(D1):940-6.

6. Jonquet C, Musen MA, Shah N. A system for ontology-based annotation of biomedical data. In: Bairoch A, Cohen-Boulakia S, Froidevaux C, editors. Data Integration in the Life Sciences. Berlin, Heidelberg: Springer; 2008. p. 144-52.

7. Kafkas \$̧, Dunham I, McEntyre J. Literature evidence in open targets-a target validation platform. J Biomed Semant. 2017;8(1):20.

8. Leaman R, Islamaj Doğan R, Lu Z. Dnorm: disease name normalization with pairwise learning to rank. Bioinformatics. 2013;29(22):2909-17.

9. Wong W, Liu W, Bennamoun M. Ontology learning from text: A look back and into the future. ACM Comput Surv. 2012;44(4):1-36. https://doi. org/10.1145/2333112.2333115.

10. Brewster C. Book review: Ontology learning from text: Methods, evaluation and applications, edited by Paul Buitelaar, Philipp Cimiano and Bernado Magnini. Comput Linguist. 2006;32(4):569-72. https://doi.org/10. 1162/coli.2006.32.4.569.

11. Lee J-B, Kim J-j, Park JC. Automatic extension of Gene Ontology with flexible identification of candidate terms. Bioinformatics. 2006;22(6): 665-70. https://doi.org/10.1093/bioinformatics/btl010.

12. Ashburner M, Ball CA, Blake JA, Botstein D, Butler H, Cherry JM, Davis AP, Dolinski K, Dwight SS, Eppig JT, Harris MA, Hill DP, Issel-Tarver L, Kasarskis A, Lewis S, Matese JC, Richardson JE, Ringwald M, Rubin GM Sherlock G. Gene ontology: tool for the unification of biology. Nat Genet. 2000;25(1):25-9. https://doi.org/10.1038/75556.

13. Wächter T, Schroeder M. Semi-automated ontology generation within OBO-Edit. Bioinformatics. 2010;26(12):88-96.

14. Xiang Z, Zheng J, Lin Y, He Y. Ontorat: Automatic generation of new ontology terms, annotations, and axioms based on ontology design patterns. J Biomed Semant. 2015;6(1):. https://doi.org/10.1186/20411480-6-4.

15. Liu F, Li G. The extension of domain ontology based on text clustering. 10th International Conference on Intelligent Human-Machine Systems and Cybernetics (IHMSC). China. 2018;01:301-4. https://doi.org/10.1109/ IHMSC.2018.00076.

16. Doğan RI, Leaman R, Lu Z. NCBI disease corpus: A resource for disease name recognition and concept normalization. J Biomed Inform. 2014;47: 1-10. https://doi.org/10.1016/j.jbi.2013.12.006.

17. Xie C, Mao X, Huang J, Ding Y, Wu J, Dong S, Kong L, Gao G, Li C-Y, Wei L. Kobas 2.0: a web server for annotation and identification of enriched pathways and diseases. Nucleic Acids Res. 2011;39(suppl_2):316-22.

18. Osborne JD, Flatow J, Holko M, Lin SM, Kibbe WA, Zhu LJ, Danila MI, Feng G, Chisholm RL. Annotating the human genome with disease ontology. BMC Genomics. 2009;10(1):6.

19. Hoehndorf R, Schofield PN, Gkoutos GV. Analysis of the human diseasome using phenotype similarity between common, genetic, and infectious diseases. Sci Rep. 2015:5:10888.

20. Rebholz-Schuhmann D, Arregui M, Gaudan S, Kirsch H, Jimeno A. Text processing through web services: calling whatizit. Bioinformatics. 2007;24(2):296-8.

21. Consortium EP. Europe pmc: a full-text literature database for the life sciences and platform for innovation. Nucleic Acids Res. 2014;43(D1): 1042-8.

22. Mikolov T, Sutskever I, Chen K, Corrado GS, Dean J. Distributed representations of words and phrases and their compositionality. In: Advances in Neural Information Processing Systems. New York: Curran Associates Inc.; 2013. p. 3111-9.

23. Rosenblatt $F$. The perceptron: a probabilistic model for information storage and organization in the brain. Psychol Rev. 1958;65(6):386

24. Vapnik VN. The Nature of Statistical Learning Theory. Berlin, Heidelberg: Springer; 1995.

25. Hemanth DJ, Estrela W. Deep Learning for Image Processing Applications. Advances in Parallel Computing, vol 31. Amsterdam: IOS Press; 2017, pp. 27-49.

26. Grau BC, Horrocks I, Motik B, Parsia B, Patel-Schneider P, Sattler U. OWL 2: The next step for owl. Web Semant Sci Serv Agents World Wide Web. 2008;6(4):309-22.

27. Smith B, Ashburner M, Rosse C, Bard J, Bug W, Ceusters W, Goldberg LJ, Eilbeck K, Ireland A, Mungall CJ, et al. The OBO foundry: coordinated evolution of ontologies to support biomedical data integration. Nat Biotechnol. 2007;25(11):1251.
28. Malone J, Holloway E, AdamusiakT, Kapushesky M, Zheng J, Kolesnikov N, Zhukova A, Brazma A, Parkinson H. Modeling sample variables with an experimental factor ontology. Bioinformatics. 2010;26(8):1112-8.

29. Maaten Lvd, Hinton G. Visualizing data using T-SNE. J Mach Learn Res. 2008;9:2579-605

30. Lynde CB, Bruce AJ, Rogers RS. Successful Treatment of Complex Aphthosis With Colchicine and Dapsone. Arch Dermatol. 2009;145(3): 273-6. https://doi.org/10.1001/archdermatol.2008.591. http://arxiv.org/ abs/https://jamanetwork.com/journals/jamadermatology/articlepdf/ 711961/dst80026_273_276.pdf.

31. Liang MW, Neoh CY. Oral aphthosis: management gaps and recent advances. Ann Acad Med Singap. 2012;41(10):463-70.

32. Murgu SD, Colt HG. Tracheobronchomalacia and excessive dynamic airway collapse. Respirology. 2006;11(4):388-406.

33. Morrison RJ, Hollister SJ, Niedner MF, Mahani MG, Park AH, Mehta DK, Ohye RG, Green GE. Mitigation of tracheobronchomalacia with $3 d$-printed personalized medical devices in pediatric patients. Sci Trans Med. 2015;7(287):287

34. Bairdain S, Smithers CJ, Hamilton TE, Zurakowski D, Rhein L, Foker JE, Baird C, Jennings RW. Direct tracheobronchopexy to correct airway collapse due to severe tracheobronchomalacia: Short-term outcomes in a series of 20 patients. J Pediatr Surg. 2015;50(6):972-7. https://doi.org/10. 1016/j.jpedsurg.2015.03.016.

35. Liu J, Liu D, Yang B, Yan J, Pu Y, Zhang J, Wen M, Yang Z, Liu L. Reversible splenial lesion syndrome (resles) coinciding with cerebra venous thrombosis: a report of two cases. Ther Adv Neurol Disord. 2017;10(12):375-9.

36. Zhang S, Ma Y, Feng J. Clinicoradiological spectrum of reversible splenial lesion syndrome (resles) in adults: a retrospective study of a rare entity. Medicine. 2015;94(6):512.

37. Martins J, Moreira S, Carneiro Â, Vila-Chã N. Progressive supranuclear palsy motor phenotype in a patient with pineocytoma. Neurology. 2016;87(3):340. https://doi.org/10.1212/WNL.0000000000002870. https://n.neurology.org/content/87/3/340.full.pdf.

38. Fakhran S, Escott EJ. Pineocytoma mimicking a pineal cyst on imaging: True diagnostic dilemma or a case of incomplete imaging? Am J Neuroradiol. 2008;29(1):159-63. https://doi.org/10.3174/ajnr.A0750. http://www.ajnr.org/content/29/1/159.full.pdf

39. Katchanov J, Sawanyawisuth K, Chotmongkol V, Nawa Y. Neurognathostomiasis, a neglected parasitosis of the central nervous system. Emerg Infect Dis. 2011;17(7):1174.

40. Penchom J, Pewpan MI, Hiroshi Y, Porntip L, Kittisak S, Chaisiri W, Chatchai T, Amnat K, Viraphong L, Yukifumi N, Wanchai M. A recombinant matrix metalloproteinase protein from gnathostoma spinigerum for serodiagnosis of neurognathostomiasis. Korean J Parasitol. 2013;51(6):751-4. https://doi.org/10.3347/kjp.2013.51.6.751. http:// parasitol.kr/journal/view.php?number=1744.

41. Kulkarni S, Sayed R, Garg M, Patil V. Neurognathostomiasis in a young child in india: A case report. Parasitol Int. 2015;64(5):342-4. https://doi. org/10.1016/j.parint.2015.05.008.

42. Taube T, Beneton MNC, McCloskey EV, Rogers S, Greaves M, Kanis JA. Abnormal bone remodelling in patients with myelomatosis and normal biochemical indices of bone resorption. Eur J Haematol. 1992;49(4):192-8. https://doi.org/10.1111/j.1600-0609.1992.tb00046.x. http://arxiv.org/abs/ https://onlinelibrary.wiley.com/doi/pdf/10.1111/j.1600-0609.1992. tb00046.xhttps://onlinelibrary.wiley.com/doi/pdf/10.1111/j.16000609.1992.tb00046.x.

43. Nieuwenhuizen L, Biesma DH. Central nervous system myelomatosis: review of the literature. Eur J Haematol. 2008;80(1):1-9. https://doi.org/10. 1111/j.1600-0609.2007.00956.x. https://onlinelibrary.wiley.com/doi/pdf/10.1111/j.1600-0609.2007.00956.x.

44. Badhwar A, Brodtmann A, Trenkwalder C, Andermann E, Andermann F, Rivest J, Caviness J, Dowling JP, Winkelmann J, Berzen L, Lambert M, Gonzales M, Hernandez-Cossio O, Berkovic SF, Narayanan S, Carpenter S. Action myoclonus-renal failure syndrome: characterization of a unique cerebro-renal disorder. Brain. 2004;127(10):2173-82. https://doi.org/10. 1093/brain/awh263. http://oup.prod.sis.lan/brain/article-pdf/127/10/ 2173/1130417/awh263.pdf.

45. Chrcanovic BR, Gomez RS. Ameloblastic fibrodentinoma and ameloblastic fibro-odontoma: An updated systematic review of cases 
reported in the literature. J Oral Maxillofac Surg. 2017;75(7):1425-37. https://doi.org/10.1016/j.joms.2016.12.038.

46. Takeda Y, Sato H, Satoh M, Nakamura S, Yamamoto H. Pigmented ameloblastic fibrodentinoma: a novel melanin-pigmented intraosseous odontogenic lesion. Virchows Arch. 2000;437(4):454-8. https://doi.org/10. 1007/s004280000249.

47. Penttilä M, Savolainen S, Kiukaanniemi $H$, Forsblom B, Jousimies-Somer $H$. Bacterial findings in acute maxillary sinusitis - european study. Acta Otolaryngol. 1997;117(sup529):165-8.

48. $\mathrm{OH} \mathrm{JJ,} \mathrm{KIM} \mathrm{CH.} \mathrm{Gastroparesis} \mathrm{after} \mathrm{a} \mathrm{presumed} \mathrm{viral} \mathrm{illness:} \mathrm{Clinical} \mathrm{and}$ laboratory features and natural history. Mayo Clin Proc. 1990;65(5): 636-42. https://doi.org/10.1016/S0025-6196(12)65125-8.

49. Kundu S, Rogal S, Alam A, Levinthal DJ. Rapid improvement in post-infectious gastroparesis symptoms with mirtazapine. World J Gastroenterol. 2014;20(21):6671.

50. Pili FMG, Erriu M, Piras A, Garau V. Application of the novel method in the diagnosis and treatment of median rhomboid glossitis candida-associated. Eur J Dent. 2014;8(1):129-31. https://doi.org/10.4103/ 1305-7456.126268.

51. Brzecka A, Leszek J, Ashraf GM, Ejma M, Ávila-Rodriguez MF, Yarla NS, Tarasov W, Chubarev VN, Samsonova AN, Barreto GE, Aliev G. Sleep disorders associated with alzheimer's disease: A perspective. Front Neurosci. 2018;12:330. https://doi.org/10.3389/fnins.2018.00330.

52. dos Santos AB, Kohlmeier KA, Barreto GE. Are sleep disturbances preclinical markers of parkinson's disease? Neurochem Res. 2015;40(3): 421-7. https://doi.org/10.1007/s11064-014-1488-7.

53. Pedroso JL, Braga-Neto P, Felício AC, Dutra LA, Santos WAC, do Prado GF, Barsottini OGP. Sleep disorders in machado-joseph disease: Frequency, discriminative thresholds, predictive values, and correlation with ataxia-related motor and non-motor features. Cerebellum. 2011;10(2): 291-5. https://doi.org/10.1007/s12311-011-0252-7.

54. Piano C, Bentivoglio AR, Cortelli P, Marca GD. Motor-related sleep disorders in huntington disease. a comment on: Neute et al.: "nocturnal agitation in huntington disease is caused by arousal-related abnormal movements rather than by rapid eye movement sleep behavior disorder" by neutel et al. Sleep Med. 2016;20:172-3. https://doi.org/10.1016/j.sleep. 2015.08.008.

55. Kono S. Chapter six - aceruloplasminemia: An update. In: Bhatia KP, Schneider SA, editors. Metal Related Neurodegenerative Disease. International Review of Neurobiology, vol 110. Cambridge: Academic Press; 2013. p. 125-51. https://doi.org/10.1016/B978-0-12-410502-7. 00007-7.

56. Tauber B, Munro J, Nickle L, Giglio M, Schor M, Felix V, Schriml LM, Mitraka E, Hyman B, Greene C, Le C, Bearer C, Bisordi K, Jeng L, Campion N, Sreekumar P, Lichenstein R, Kibbey S, Kurland D, Oates CP. Human Disease Ontology 2018 update: classification, content and workflow expansion. Nucleic Acids Res. 2018;47(D1):955-62. https://doi. org/10.1093/nar/gky1032. http://oup.prod.sis.lan/nar/article-pdf/47/D1/ D955/27437186/gky1032.pdf.

57. Pletscher-Frankild S, Pallejà A, Tsafou K, Binder JX, Jensen LJ. Diseases: Text mining and data integration of disease-gene associations. Methods. 2015;74:83-9. https://doi.org/10.1016/j.ymeth.2014.11.020.

58. Collier N, Oellrich A, Groza T. Toward knowledge support for analysis and interpretation of complex traits. Genome Biol. 2013;14(9):214. https://doi. org/10.1186/gb-2013-14-9-214.

59. Collier N, Tran M-V, Le H-Q, Oellrich A, Kawazoe A, Hall-May M, Rebholz-Schuhmann D. A hybrid approach to finding phenotype candidates in genetic texts. In: Proceedings of COLING 2012. Mumbai: The COLING 2012 Organizing Committee; 2012. p. 647-62.

60. Kafkas S, Abdelhakim M, Hashish Y, Kulmanov M, Abdellatif M, Schofield PN, Hoehndorf R. Pathophenodb, linking human pathogens to their phenotypes in support of infectious disease research. Sci Data. 2019;6(1):79. https://doi.org/10.1038/s41597-019-0090-x.

61. Kafkas $S$, Hoehndorf R. Ontology based mining of pathogen-disease associations from literature. J Biomed Semant. 2019;10(1):15. https://doi. org/10.1186/s13326-019-0208-2.

62. Rebholz-Schuhmann D, Kafkas S, Kim J-H, Yepes AJ, Lewin I. Monitoring named entity recognition: the league table. J Biomed Semant. 2013;4(1): 19. https://doi.org/10.1186/2041-1480-4-19.

63. Sewell W. Medical subject headings in medlars. Bull Med Libr Assoc. 1964;52(1):164-70.
64. Hamosh A, Scott AF, Bocchini CA, Amberger JS, McKusick VA. Online Mendelian Inheritance in Man (OMIM), a knowledgebase of human genes and genetic disorders. Nucleic Acids Res. 2005;33:514-7. https://doi.org/ 10.1093/nar/gki033.

\section{Publisher's Note}

Springer Nature remains neutral with regard to jurisdictional claims in published maps and institutional affiliations.

\section{Ready to submit your research? Choose BMC and benefit from:}

- fast, convenient online submission

- thorough peer review by experienced researchers in your field

- rapid publication on acceptance

- support for research data, including large and complex data types

- gold Open Access which fosters wider collaboration and increased citations

- maximum visibility for your research: over $100 \mathrm{M}$ website views per year

At BMC, research is always in progress.

Learn more biomedcentral.com/submissions 